\title{
The skeletal remains from Babacan Village Early Iron Age (Muradiye, Van, Turkey)
}

\author{
Hakan Y1maz ${ }^{1}$
}

\begin{abstract}
Human skeletal remains were found from tomb dated to Early Iron Age in the Babacan Village in which is a town in the district of Muradiye $(18 \mathrm{~km})$, Van province $(105 \mathrm{~km})$, Turkey. Human bones were unearthed from tomb during an illegal excavation in the eastern province of Van's Muradiye Babacan Village district. The bones were examined for age, sex and also presence of pathological. Furthermore, skeletal measurements and indices were calculated. A minimum of five individuals was defined from tomb dated to Early Iron Age. Skeletal remains in Babacan Village are composed of at least five individuals, including adult of both sexes (four male, one female). The average age of five individuals were calculated as $>30$ years. This age is similar to other Early Iron Age populations Van area. Assessing the paleopathological lesions were not observed on the skeletal remains Babacan Village burials. Moreover, another paleopathological observation was not found on the human bones, including trauma.
\end{abstract}

Keywords: anthropological assessment, human bones, early Iron Age

\section{Introduction}

\section{Anthropological Analysis}

Skeletal remains in a very few numbers of preservation were unearthed during an illegal excavation in the Babacan Village. The bones were found from tomb dated to Early Iron Age. The fragmentary nature of the remains did not allow for a comprehensive study of the skeletal population. The anthropological profile of the collection buried in this tomb was recreated and contains estimation of the minimum number of individuals (MNI) buried in the tomb. Age end sex was shown distribution (Table 1); metric morphological description of the long bones (Table 2) and a brief definition of pathologies.

The skeletal remains in the tomb stand for at least 5 individuals, the all of them identified as adult males and females. The average age at death of adult was calculated at 20 to 35 years. The estimation of age was based on phases of the spongiosa structure of the femur head and cranial suture closure (WEA, 1980). The sex estimations were based upon state of large, gracile and robust of the long bones and cranial morphology (Ubelaker 1989). Especially, maximum diameters of the

\footnotetext{
${ }^{1}$ Res.Asst. Dr., Yüzüncü Y1l University, Lieracy Faculty, Department of Anthropology, Van, hakanyilmaz@yyu.edu.tr
} 
Yllmaz, H. (2015). The skeletal remains from Babacan Village Early Iron Age (Muradiye, Van, Turkey). International Journal of Human Sciences, 12(1), 1394-1396. doi: 10.14687/ijhs.v11i2.3085

heads of the femur, humerus, and radius are quite indicators of sex in adults when there are not cranium and pelvis (Ubelaker 1989).

\begin{tabular}{|lll|}
\hline MNI & Sex & Age \\
\hline Individula 1 & Male & Adult $(20-30)$ \\
Individula 2 & Male & Adult $(20-25)$ \\
Individula 3 & Male & Adult $(20-30)$ \\
Individula 4 & Male & Adult $>35$ \\
Individula 5 & Female & Adult $(20-30)$ \\
\hline
\end{tabular}

Table 1. Anthropological Data of the Skeletal Remains Babacan Village.

Table 2 presents the postcranial skeleton measurements. Measuring technique and standard terminology were basically taken by Buikstra and Ubelaker (1994). All measurements were taken with standard equipment. All indexes were calculated by Microsoft Excel program.

\begin{tabular}{|c|c|c|c|c|c|c|c|c|}
\hline $\begin{array}{l}\text { Femur } \\
(\mathrm{mm})\end{array}$ & M.r.s. ${ }^{2}$ & F.r.s. ${ }^{3}$ & M.r.s. & M.r.s. & F.r.s. & M.l.s. ${ }^{4}$ & M.l.s. & M.l.s. \\
\hline $\begin{array}{l}\text { Neck transverse } \\
\text { diameter }\end{array}$ & 29,9 & 22,63 & & & & & 29,39 & \\
\hline $\begin{array}{l}\text { Neck vertical } \\
\text { diameter }\end{array}$ & 35,11 & 26,89 & & & & & 36,89 & \\
\hline $\begin{array}{l}\text { Medial- } \\
\text { lateral } \\
\text { subtrochanteric } \\
\text { diameter }\end{array}$ & 34,56 & 30,24 & 34,47 & 35,48 & 31,83 & 35,72 & 41,96 & 37,63 \\
\hline $\begin{array}{l}\text { Anterior-posterior } \\
\text { subtrochanteric } \\
\text { diameter }\end{array}$ & 23,88 & 17,43 & 24,9 & 24,44 & 23,44 & 25,63 & 28,91 & 28,16 \\
\hline $\begin{array}{l}\text { Medial-lateral } \\
\text { diameter at } \\
\text { midshaft }\end{array}$ & 29,90 & & 28,08 & 28,94 & 26,95 & 29,83 & 34,37 & 31,38 \\
\hline $\begin{array}{l}\text { Anterior-posterior } \\
\text { diameter at } \\
\text { midshaft }\end{array}$ & 29,54 & & 27,44 & 27,96 & 22,39 & 28,5 & 29,42 & 29,5 \\
\hline $\begin{array}{l}\text { Plastric } \\
\text { index }\end{array}$ & 98,80 & & 97,72 & 96,61 & 83,08 & 95,54 & 85,60 & 94,01 \\
\hline Platymeric index & 69,10 & 57,64 & 72,24 & 68,88 & 73,64 & 71,75 & 68,90 & 74,83 \\
\hline
\end{tabular}

\footnotetext{
2 Male right side .

${ }^{3}$ Female right side.

${ }^{4}$ Male left side.
} 
Yllmaz, H. (2015). The skeletal remains from Babacan Village Early Iron Age (Muradiye, Van, Turkey). International Journal of Human Sciences, 12(1), 1394-1396. doi: 10.14687/ijhs.v11i2.3085

Table 2. Skeletal Measurements and Indices of the Babacan Village (Femur Measurements)

\begin{tabular}{|lccccc|}
\hline Tibia $(\mathrm{mm})$ & F.l.s. & M.l.s. & M.l.s. & M.l.s. & M.r.s. \\
\hline $\begin{array}{l}\text { Shaft diameter at nutrient } \\
\text { foramen (mediolateral) }\end{array}$ & 18,37 & & 21,41 & & 21,5 \\
$\begin{array}{l}\text { Shaft diameter at nutrient } \\
\text { foramen (anteroposterior) } \\
\begin{array}{l}\text { Proximal epiphyseal breadth } \\
\text { Platycnemic index }\end{array}\end{array}$ & 28,74 & & 31,43 & & 35,76 \\
\hline
\end{tabular}

Table 2. Skeletal Measurements and Indices of the Babacan Village (Tibia Measurements).

\begin{tabular}{|lccc|}
\hline Humerus & M.l.s. & M.r.s. & M.r.s. \\
\hline Maximum midshaft diameter & 21,22 & 23,15 & 21,03 \\
Minimum midshaft diameter & 17,92 & 19,33 & 16,89 \\
Diaphyseal index & 84,45 & 83,50 & 80,31 \\
\hline
\end{tabular}

Table 2. Skeletal Measurements and Indices of the Babacan Village (Humerus Measurements).

\section{Paleopathological Analysis}

Evidence of a pathological lesion that affected the bones could not be traced in the all of bones.

\section{Conclusions}

Despite the very poor state of preservation of the skeletal remains from Babacan village, palaeodemographic analysis was made possible by sorting the long bone collected from this site according to their spongiosa structure of the femur head stages. The results show a minimum of 5 individuals buried in the tomb Early Iron Age.

\section{References}

Buikstra, J.E. ve Ubelaker, D., 1994, Standarts for Data Collection from Human Skeletal Remains, Arkansas Archeological Survey Research Series No:44, Arkansas, USA.

Ubelaker, D.H., 1989, Human Skeletal Remains: Excavation, Analysis, Interpretation (2 ${ }^{\text {nd }}$ Edition), the Manuals on Archeology, Taraxacum, Washington USA.

Workshop of European Anthropologists, 1980, "Recommendations for Age and Sex Diagnoses of Skeletons", Journal of Human Evolution, 9:517-549. 